\title{
Dietary Replacement with Food Waste and Black Soldier Fly Larvae Supplementation Improved Growth Performance, Nutrient Digestibility and Intestinal Microbial Population in Broilers
}

\author{
Mohammed Al-Qazzaz ${ }^{1 \dagger}$, Anjas Asmara Samsudin ${ }^{2}$, Lokman Hakim Idris ${ }^{3}$, Dahlan Ismail ${ }^{2}$ and Henny Akit ${ }^{2,4 *}$ \\ ${ }^{1}$ Animal Resources Department, Faculty of Agriculture, University of Baghdad, Baghdad, Iraq \\ ${ }^{2}$ Animal Science Department, Faculty of Agriculture, Universiti Putra Malaysia, 43400 UPM Serdang, Selangor, Malaysia \\ ${ }^{3}$ Department of Veterinary Pre-Clinical Science, Faculty of Veterinary Medicine, Universiti Putra Malaysia, 43400 UPM \\ Serdang, Selangor, Malaysia \\ ${ }^{4}$ Institute of Bioscience, Universiti Putra Malaysia, 43400 UPM Serdang, Selangor, Malaysia \\ *For correspondence: henny@upm.edu.my; mohfa77@hotmail.com \\ †Contributed equally to this work and are co-first authors \\ Received 13 October 2020; Accepted 05 January 2021; Published 10 May 2021
}

\begin{abstract}
This study was aimed to evaluate the effect of conventional ingredients replacement with alternative ingredients on growth performance, carcass quality, nutrient digestibility and intestinal microbial of broilers. One hundred twenty Cobb500 broiler chicks were randomly assigned to four diets. Corn, soybean meal and fish meal were replaced with rice waste, meat and bone waste and black soldier fly larvae (BSFL) at 0,10,30 and 50\% to form four treatments. Body weight gain, feed conversion ratio and digestibility of crude protein and fat were improved in broilers fed the replacement diets. Feed intake was not affected by the treatments suggesting that the replacement diets were well accepted by the chicken. Escherichia coli was decreased in the cecum and Lactobacillus were increased in the intestines of broilers fed the replacement diets. The fiber and chitin contents in the replacement diets may alter intestinal bacterial fermentation leading to improved nutrient digestibility. However, abdominal fat percentage increased in broilers fed the replacement diets. In conclusion, conventional ingredients can be replaced with up to $50 \%$ rice waste, meat and bone waste and BSFL in the diets with promising effect on growth performance, nutrient digestibility and intestinal microbial populations. (C) 2021 Friends Science Publishers
\end{abstract}

Keywords: Black soldier fly larvae; Broiler; Food waste; Microbial population; Nutrient digestibility

\section{Introduction}

Food waste is disposed in landfills and decomposition of food waste in landfills contributes to the greenhouse gas emission. Utilization of food waste as part of the chicken diet can divert food waste from landfills and offer viable solution to mitigate its negative impact on the environment. In the current study, food waste is defined as leftover food not consumed by consumers sourced from restaurants (Parfitt et al. 2010). Depending on the demographic and consumer's eating behavior, the leftover typically consists of meat and bone, rice, vegetables, fruits, meat trimmings and grease. Food wastes have adequate but highly variable nutritional values depending on the sourced leftovers; dry matter ( 85.3 to $91.6 \%)$, crude protein $(14.4$ to $28.3 \%)$ and ether extract (9.1 to $31.5 \%$ ). The fiber content can vary from 3.7 to $14.5 \%$ (Chen et al. 2007, 2015; Nadia et al. 2016) depending on the content of fruit and vegetables in the leftovers. The growth performance of chickens improved with inclusion of black soldier fly larvae (BSFL) in the diets
(Oluokun 2000; Marono et al. 2017). The exoskeleton of BSFL contains chitin that could promote diverse gut bacterial communities, improving the gut health of hens (Borrelli et al. 2017). Owing to the properties of BSFL, we hypothesized that the dietary combinations of food wastes and BSFL could improve the growth performance of broilers. To test the hypothesis, corn, soybean meal and fish meal were replaced with rice waste, meat and bone waste as well as BSFL, respectively. The aim of the study was to evaluate the effect of replacing conventional feed ingredients with alternative ingredients on growth performance, nutrient digestibility, carcass quality and intestinal microbial population of broilers.

\section{Materials and Methods}

\section{Animals and diets}

The approved protocol of the Institutional Animal Care and Use Committee of the Universiti Putra Malaysia 
(UPM/IACUC/AUP-R053/2017) was applied in all animal handling procedures. Food wastes were collected and pooled daily from the restaurants around Serdang, Malaysia. The food wastes were then separated into two parts. One part contained rice waste as an energy source, while the other part contained meat and bone waste as a protein source. Then, the food wastes were processed daily by washing using tap water, followed by immersing in hot water at $90^{\circ} \mathrm{C}$ for $10 \mathrm{~min}$ and then oven-drying at $60^{\circ} \mathrm{C}$ for two days (Hossein and Dahlan 2015). Live BSFL younger than seven days old were oven-dried at $60^{\circ} \mathrm{C}$ for five days. A total of 120 Cobb 500 female broiler chicks (one day old) were randomly allocated to four treatment groups with six replicates per treatment (five birds per replicate). The control treatment (T1) consisted of corn, soybean meal and fish meal with $0 \%$ replacement with alternative ingredients. The second treatment (T2) consisted of corn replaced with $10 \%$ rice waste, soybean meal replaced with $10 \%$ meat and bone waste and fish meal replaced with $10 \%$ BSFL. The third treatment (T3) contained conventional ingredients replaced with $30 \%$ alternative ingredients and the fourth treatment (T4) contained conventional ingredients replaced with $50 \%$ alternative ingredients. The experimental diets were formulated to be isonitrogenous and isocaloric across treatments (Table 1). Feed and water were provided at ad libitum. Vaccinations against Newcastle and Gumboro diseases were administered to the birds at 7 and 21 days old.

\section{Growth performance and carcass quality}

Body weight gain and feed intake of the birds were measured weekly and subsequently, feed conversion ratio (FCR) was calculated. Two birds from each replicate were randomly selected and slaughtered on 21 and 42 days of age. Dressing percentage was determined by dividing the carcass weight over the live weight. Pectoralis major muscle (breast) percentage was calculated by dividing a percentage of the breast weight over the live weight. Abdominal fat percentage was calculated by dividing a percentage of the abdominal fat weight over the live weight.

\section{Nutrient digestibility}

Titanium dioxide $\left(\mathrm{TiO}_{2}\right)$ was added to all diets as an indigestible marker at $5 \mathrm{~g} / \mathrm{kg}$, four days prior to slaughtering. Digesta samples were pooled from the ileum (Merckel's diverticulum to the ileal-cecal junction), then oven-dried at $60^{\circ} \mathrm{C}$ for two days prior to storing at $-20^{\circ} \mathrm{C}$. Proximate analysis of dry matter, crude protein, ash, ether extract, crude fiber, gross energy and $\mathrm{TiO}_{2}$ were conducted on the homogenized samples of the diets and ileal digesta (AOAC 2005). Apparent nutrient digestibility was determined using the following equation;

Apparent nutrient digestibility $(\%)=100-\left[100 \times\left(\% \mathrm{TiO}_{2}\right.\right.$ in feed $/ \%$ $\mathrm{TiO}_{2}$ in digesta $) \times(\%$ nutrient in digesta/\%nutrient in feed $\left.)\right] \times 100$.

\section{Quantification of the bacterial populations in the ileum} and caecum

On day 42 , eight birds from each treatment were slaughtered for collection of digesta samples from the cecum and ileum prior to storing at $-20^{\circ} \mathrm{C}$. The samples were then subjected to DNA extraction using the QIAamp ${ }^{\circledR}$ Fast DNA Stool Mini kit (Qiagen, Valencia, CA, U.S.A.). A total of $200 \mathrm{mg}$ sample was collected in a microcentrifuge tube that was placed on ice. Then, $1 \mathrm{~mL}$ InhibitEX Buffer was added to the sample and suspended by vortex for $1 \mathrm{~min}$. The samples were subjected to follow the manufacturer's instructions.

\section{Quantitative real time-polymerase chain reaction (RT- PCR)}

Specific primers $(10 \mathrm{ng} / \mathrm{mL}$ concentration) of different bacterial populations were used for bacterial quantification (Table 2). The amplification reactions were conducted using BioRad CFX96 Touch $^{\circledR}$ (BioRad, Hercules, C.A., U.S.A.). The extracted DNA of the samples was used as a template in the PCR assay. The reaction volume was $25 \mu \mathrm{L}$, consisting of $1 \mu \mathrm{L}$ of DNA, 12.5 SYBR Green, $1 \mu \mathrm{L}$ forward primer, $1 \mu \mathrm{L}$ reverse primer, and $9.5 \mu \mathrm{L}$ RNaes-free water. The amplification conditions were set at $94^{\circ} \mathrm{C}$ for 5 min, followed by 40 cycles of $94^{\circ} \mathrm{C} \times 20 \mathrm{~s}$, primer annealing at 58, 50, 60 and $50^{\circ} \mathrm{C} \times 30 \mathrm{~s}$ for Lactobacillus, Enterococcus, Bifidobacterium and Escherichia coli, respectively, which was then extended to $72^{\circ} \mathrm{C} \times 20 \mathrm{~s}$.

\section{Statistical analysis}

One-way ANOVA analysis was applied using the GLM procedure of SAS software (SAS Institute Inc., Cary, NC, USA) for all data. The differences among treatments were determined using the Duncan's new multiple range test, and the significant differences among treatment means were determined at $P<0.05$.

\section{Results}

\section{Growth performance and carcass quality}

The effect of replacement diets on the growth performance of broilers is shown in Table 3. In the starter period, dietary treatments had no effect on the feed intake $(P>0.05)$. Body weight gain was higher in birds fed the replacement diets than the control diet $(P<0.01)$. Body weight was the highest in the birds fed 30 and $50 \%$ replacement diets $(P$ $<0.05)$. Feed conversion ratio was the lowest in the birds fed 10 and $30 \%$ replacement diets $(P<0.05)$. In the finisher period, treatments had no effect on the feed intake and live weight $(P>0.05$, respectively). Body weight gain was the highest in the birds fed 30 and 50\% replacement diets $(P<0.05)$ and FCR was the lowest in the 10 and 30\% replacement diet groups $(P<0.05)$. In the 
Table 3: Effect of conventional ingredients replacement with 10, 30 and $50 \%$ of alternative ingredients on the growth performance of broiler chickens

\begin{tabular}{|c|c|c|c|c|c|c|}
\hline Variables & $\mathrm{T} 1$ & $\mathrm{~T} 2$ & $\mathrm{~T} 3$ & $\mathrm{~T} 4$ & SEM & $\begin{array}{l}p \\
\text { Value }\end{array}$ \\
\hline \multicolumn{7}{|l|}{$0-21$ days } \\
\hline Feed intake $(\mathrm{g})$ & 995.2 & 952.9 & 1035.5 & 1052.7 & 0.13 & ns \\
\hline Body weight gain $(\mathrm{g})$ & $608.8^{\mathrm{b}}$ & $669.4^{\mathrm{a}}$ & $710.3^{\mathrm{a}}$ & $685.6^{\mathrm{a}}$ & 0.39 & 0.01 \\
\hline Feed conversion ratio $(\mathrm{g} / \mathrm{g})$ & $1.6^{\mathrm{a}}$ & $1.4^{\mathrm{b}}$ & $1.5^{\mathrm{b}}$ & $1.5^{\mathrm{ab}}$ & 0.11 & 0.01 \\
\hline Body weight (g) & $631.2^{\mathrm{b}}$ & $703.5^{\mathrm{a}}$ & $697.4^{\mathrm{ab}}$ & $723.4^{\mathrm{a}}$ & 0.30 & 0.05 \\
\hline \multicolumn{7}{|l|}{$21-42$ days } \\
\hline Feed intake $(\mathrm{g})$ & $2244.9^{\mathrm{a}}$ & $2236.5^{\mathrm{ab}}$ & $1940.3^{b}$ & $2008.3^{\mathrm{ab}}$ & 1.94 & 0.05 \\
\hline Body weight gain $(\mathrm{g})$ & $1199.7^{b}$ & $1226.9^{\mathrm{ab}}$ & $1262.6^{\mathrm{a}}$ & $1262.4^{\mathrm{a}}$ & 1.43 & 0.05 \\
\hline Feed conversion ratio $(\mathrm{g} / \mathrm{g})$ & $1.9^{\mathrm{a}}$ & $1.8^{\mathrm{ab}}$ & $1.5^{\mathrm{b}}$ & $1.6^{\mathrm{bc}}$ & 0.18 & 0.05 \\
\hline Body weight (g) & 2076.3 & 2087.5 & 2118.0 & 2099.0 & 1.57 & ns \\
\hline \multicolumn{7}{|l|}{$0-42$ days } \\
\hline Feed intake $(\mathrm{g})$ & 3240.1 & 3129.7 & 3120.1 & 3249.6 & 1.05 & ns \\
\hline Body weight gain (g) & $1808.5^{\mathrm{b}}$ & $1896.3^{\mathrm{ab}}$ & $1929.2^{\mathrm{a}}$ & $1979.2^{\mathrm{a}}$ & 4.91 & 0.01 \\
\hline Feed conversion ratio $(\mathrm{g} / \mathrm{g})$ & $1.8^{\mathrm{a}}$ & $1.7^{\mathrm{b}}$ & $1.6^{\mathrm{b}}$ & $1.6^{\mathrm{b}}$ & 0.07 & 0.05 \\
\hline \multicolumn{7}{|c|}{$\begin{array}{l}\text { Superscripts (a-c) show significant differences among treatments in each row }(P< \\
\text { 0.05). NS: non-significant. SEM: standard error of means. } \\
\text { T1: control diet. T2: replacement of conventional ingredients with } 10 \% \text { alternative } \\
\text { ingredients. T3: replacement of conventional ingredients with } 30 \% \text { alternative } \\
\text { ingredients. T4: replacement of conventional ingredients with } 50 \% \text { alternative } \\
\text { ingredients. }\end{array}$} \\
\hline
\end{tabular}

Table 4: Effect of conventional feed ingredients replacement with 10,30 and $50 \%$ of alternative ingredients on carcass quality

\begin{tabular}{lllllll}
\hline Variables & T1 & T2 & T3 & T4 & SEM & $p$ Value \\
Carcass weight (g) & 1771.1 & 1725.0 & 1857.1 & 1789.9 & 1.32 & ns \\
Dressing (\%) & 84.2 & 86.7 & 85.8 & 85.4 & 1.30 & $\mathrm{~ns}$ \\
Breast muscle (\%) & 25.9 & 24.5 & 26.3 & 24.8 & 2.93 & $\mathrm{~ns}$ \\
Abdominal fat (\%) & $1.1^{\mathrm{b}}$ & $1.6^{\mathrm{ab}}$ & $2.2^{\mathrm{a}}$ & $2.0^{\mathrm{a}}$ & 0.65 & 0.05 \\
\hline
\end{tabular}

Superscripts (a-b) show significant differences among treatments in each row $(p<0.05)$. NS: non-significant. SEM: standard error of means. T1: control diet. T2: replacement of conventional ingredients with $10 \%$ alternative ingredients. T3: replacement of conventional ingredients with $30 \%$ alternative ingredients. T4: replacement of conventional ingredients with $50 \%$ alternative ingredients

Table 5: Effect of conventional feed ingredients replacement with 10,30 and $50 \%$ of alternative ingredients on nutrient digestibility

\begin{tabular}{|c|c|c|c|c|c|c|}
\hline Nutrient digestibility (\%) & $\mathrm{T} 1$ & $\mathrm{~T} 2$ & T3 & $\mathrm{T} 4$ & SEM & $p$ Value \\
\hline \multicolumn{7}{|l|}{ 0-21 days } \\
\hline Dry matter & $89.0^{\mathrm{d}}$ & $90.9^{c}$ & $92.8^{\mathrm{a}}$ & $91.8^{\mathrm{b}}$ & 0.04 & 0.001 \\
\hline Crude protein & $83.5^{\mathrm{c}}$ & $85.7^{\mathrm{ab}}$ & $84.4^{\mathrm{b}}$ & $86.8^{\mathrm{a}}$ & 0.84 & 0.001 \\
\hline Ether extract & $81.3^{\mathrm{c}}$ & $85.9^{\mathrm{b}}$ & $90.3^{\mathrm{a}}$ & $89.5^{\mathrm{a}}$ & 1.04 & 0.001 \\
\hline Ash & $88.6^{\mathrm{d}}$ & $90.5^{\mathrm{c}}$ & $91.9^{\mathrm{a}}$ & $91.2^{\mathrm{b}}$ & 0.13 & 0.001 \\
\hline Crude fibre & 77.2 & 82.6 & 87.5 & 84.6 & 0.85 & ns \\
\hline \multicolumn{7}{|l|}{ 21-42 days } \\
\hline Dry matter & $89.0^{\mathrm{d}}$ & $91.0^{\mathrm{c}}$ & $92.8^{\mathrm{a}}$ & $91.6^{\mathrm{b}}$ & 0.09 & 0.001 \\
\hline Crude protein & $88.8^{\mathrm{d}}$ & $92.2^{\mathrm{b}}$ & $91.3^{\mathrm{c}}$ & $94.6^{\mathrm{a}}$ & 0.30 & 0.001 \\
\hline Ether extract & $92.5^{\mathrm{b}}$ & $91.5^{\mathrm{b}}$ & $96.6^{\mathrm{a}}$ & $96.2^{\mathrm{a}}$ & 0.70 & 0.001 \\
\hline Ash & $89.0^{\mathrm{c}}$ & $90.6^{\mathrm{b}}$ & $92.2^{\mathrm{a}}$ & $90.9^{\mathrm{b}}$ & 0.10 & 0.001 \\
\hline Crude fibre & 74.8 & 78.0 & 79.8 & 74.3 & 0.54 & ns \\
\hline \multicolumn{7}{|c|}{$\begin{array}{l}\text { Superscripts (a-c) show significant differences among treatments in each row } \\
(p<0.05) \text {. NS: non-significant. SEM: standard error of means.T1: control diet. T2: } \\
\text { replacement of conventional ingredients with } 10 \% \text { alternative ingredients. T3: } \\
\text { replacement of conventional ingredients with } 30 \% \text { alternative ingredients. T4: } \\
\text { replacement of conventional ingredients with } 50 \% \text { alternative ingredients }\end{array}$} \\
\hline
\end{tabular}

populations in the ileum and cecum of broilers $(P>0.05$, respectively) were not affected by treatments. Birds fed the 30 and 50\% replacement diets had higher Enterococcus population in the ileum compared to the control diet $(P<$ 0.05). The population of Enterococcus in the cecum recorded
Table 6: Effect of conventional feed ingredients replacement with 10,30 and $50 \%$ of alternative ingredients on ileal and cecal bacteria in broilers at 42 day of age

\begin{tabular}{|c|c|c|c|c|c|}
\hline $\begin{array}{l}\text { Microbial population }\left(\log ^{10}\right. \\
\text { copy } \mathrm{n} / \mathrm{mL} \text { DNA extract) }\end{array}$ & Organ T1 & $\mathrm{T} 2$ & $\mathrm{~T} 3$ & T4 SEM & $P$ \\
\hline \multirow[t]{2}{*}{ Bifidobacterium } & Ileum 7.9 & 10.9 & 6.6 & $7.4 \quad 3.49$ & ns \\
\hline & Cecum 9.7 & 7.9 & 9.1 & $\begin{array}{ll}7.8 & 4.72\end{array}$ & ns \\
\hline \multirow[t]{2}{*}{ Enterococcus } & Ileum $6.9^{c}$ & $6.8^{\mathrm{c}}$ & $7.4^{\mathrm{b}}$ & $\begin{array}{lll}7.9^{\mathrm{a}} & 0.13\end{array}$ & 0.001 \\
\hline & Cecum $6.6^{b}$ & $6.2^{\mathrm{b}}$ & $6.7^{\mathrm{b}}$ & $\begin{array}{lll}7.6^{\mathrm{a}} & 0.48\end{array}$ & $0 .($ \\
\hline \multirow[t]{2}{*}{ Escherichia coli } & Ileum $3.7^{\mathrm{b}}$ & $4.6^{\mathrm{a}}$ & $4.7^{\mathrm{a}}$ & $4.6^{\mathrm{a}} 0.53$ & 0.0 \\
\hline & Cecum $6.2^{\mathrm{a}}$ & $5.0^{\mathrm{c}}$ & $6.2^{\mathrm{b}}$ & $5.3^{\mathrm{b}} 0.21$ & 0.001 \\
\hline \multirow[t]{2}{*}{ Lactobacillus } & Ileum $5.7^{\mathrm{c}}$ & $6.5^{\mathrm{a}}$ & $6.0^{\mathrm{b}}$ & $6.1^{\mathrm{b}} 0.15$ & 0.001 \\
\hline & Cecum $5.8^{\mathrm{c}}$ & $5.9^{\mathrm{b}}$ & $6.0^{\mathrm{b}}$ & $6.3^{\mathrm{a}} 0.20$ & 0.01 \\
\hline \multicolumn{6}{|c|}{$\begin{array}{l}\text { Superscripts (a-c) show significant differences among treatments in each row }(P< \\
\text { 0.05). NS: non-significant. SEM: standard error of means } \\
\text { T1: control diet. T2: replacement of conventional ingredients with } 10 \% \text { alternative } \\
\text { ingredients. T3: replacement of conventional ingredients with } 30 \% \text { alternative } \\
\text { ingredients. T4: replacement of conventional ingredients with } 50 \% \text { alternative } \\
\text { inoredients }\end{array}$} \\
\hline
\end{tabular}

the highest number in the birds fed 50\% replacement diet $(P$ $<0.05)$. E. coli population increased in the ileum $(P<0.05)$ but decreased in the cecum of birds fed the replacement diets $(P<0.001)$. Birds fed the replacement diets had increased Lactobacillus populations in both the ileum $(P<0.001)$ and cecum $(P<0.01)$ compared to the control diets.

\section{Discussion}

Body weight gain and FCR improved in broilers fed mixtures of food wastes and BSFL at 30 and 50\% replacement diets. In contrast, previous studies showed that dietary inclusion of 20 to $30 \%$ of food waste had no effect on body weight gain and FCR of broilers (Saki et al. 2006; Viana et al. 2006). Chen et al. (2007) reported no difference in the weight gain of Taiwan Native chicken fed $20 \%$ food waste and the conventional diet. In the current study, broilers fed diet containing 10\% BSFL replacement had similar growth performance to the control group. On the other hand, broilers fed higher levels of BSFL at 30 and $50 \%$ replacements resulted in improved growth performance. The improved growth performance was a result of improved crude protein and fat digestibility in the broilers that received the replacement diets. Improvement of FCR with no changes in the feed intake suggests that the nutrients were utilized for body weight gain. No differences in the feed intake between treatments suggest that the replacement diets were as palatable as the control diet.

Dietary fiber plays an important role in the microbial fermentation in the cecum of chicken (Dunkley et al. 2007). The type and quantity of dietary fiber can alter the microbial populations in the guts of broilers (Mateos et al. 2012). Chen et al. (2007) reported that the crude protein digestibility was increased but energy digestibility was decreased in chickens fed $20 \%$ food waste. In the abovementioned study, the reduced energy digestibility was suggested to be due to the high fiber content of food waste 
(10.8\% crude fiber) which contained an average of $51.2 \%$ fruit and vegetables. In addition, Sadeghi et al. (2015) indicated that dietary fiber above $3 \%$ could have a negative effect on growth performance of broilers. In the current study, fruit and vegetable residuals were not included in the food waste and the dietary crude fiber was below $3 \%$. In fact, the performance of broilers improved with lower amount of fiber in the basal diet (Jiménez-Moreno et al. 2009, 2013).

E. coli population was decreased in the cecum and Lactobacillus populations were increased in the intestines of broilers fed the replacement diets. BSFL contained chitin at 50 to $96 \mathrm{~g} / \mathrm{kg}$ dry matter of BSFL (Kroeckel et al. 2012; Schiavone et al. 2017). Chitin may be responsible for the alteration of bacteria populations that could have favorable effects on nutrients digestibility in the current study. Chitin content in BSFL could be the key factor in modifying microbial fermentation (Borrelli et al. 2017). Increased butyrate and acetate levels in the caeca of hens proved that chitin was used a substrate for intestinal bacterial fermentation (Cutrignelli et al. 2018). It has been speculated that the high butyric acid level may partly be responsible for inhibiting E. coli, with no inhibition of beneficial bacteria such as Lactobacillus. Another possible explanation for the alteration of microbial populations could be due to the antimicrobial properties of BSFL (Spranghers et al. 2017). Lauric acid is the major component of BSFL that ranges from 21 to $68 \%$ of the total lipid depending on its rearing substrates (DiGiacomo et al. 2019). Lauric acid is a natural antimicrobial agent that suppressed the growth of E. coli (Dierick et al. 2002) with less impact on Lactobacilli (Spranghers et al. 2017). However, it should be noted that the impacts of chitin and lauric acid contents could be minimum considering the low level of dietary BSFL inclusion in the current study. There is limited report on the effect of food wastes and BSFL on the broiler's intestinal microbiome and this warrants further investigation.

The broilers that received the replacement diets had higher abdominal fat weight, with no changes in carcass weight and breast muscle percentage, suggesting that the increased body weight gain could be a result of increased fat deposition. It is well documented that dietary fatty acid profile could influence abdominal fat deposition. The broilers fed dietary fats rich in saturated fatty acid (SFA) had higher abdominal fat deposition compared to fats rich in polyunsaturated fatty acid (PUFA) (Crespo and EsteveGarcia 2001; Khatun et al. 2017). Meat and bone waste contained $20.39 \%$ crude fat (Alqazzaz et al. 2019). Hossein (2015) reported relatively high SFA in restaurant wastes composed of meat and chicken bones. Although not measured, the replacement diets in the current study may be rich in SFA, which is less readily available for energy production compared to PUFA. Hence, SFA was stored as adipose tissue that resulted in increased abdominal fat deposition (Velasco et al. 2010).

\section{Conclusion}

Combinations of food waste and BSFL improved the body weight gain and feed efficiency of broilers. Alteration of intestinal microbial population and improvement of crude protein and fat digestibility in the broilers that received the replacement diets could be because of a reasonable amount of fiber in the food wastes as well as chitin content and antimicrobial properties of BSFL. Rice waste and meat and bone waste could become partial substitutes for conventional ingredients that could offer viable solution to mitigate food waste's negative impact on the environment.

\section{Acknowledgements}

This research was sponsored by Putra Grant (IPS) from the Universiti Putra Malaysia. This research was funded by GP-IPS from Universiti Putra Malaysia

\section{Author Contributions}

All authors designed the experiment. MA and HA performed the experiments. MA, HA and AAS analyzed the data. All authors reviewed and offered critical comments on the manuscript.

\section{Conflict of Interest}

The authors declare that the research was conducted in the absence of any commercial or financial relationships that could be construed as a potential conflict of interest.

\section{Data Availability}

All datasets presented in this study are included in the article

\section{Ehics Approval}

The approved protocol of the Institutional Animal Care and Use Committee of the Universiti Putra Malaysia (UPM/IACUC/AUP-R053/2017) was applied in all animal handling procedures.

\section{References}

Alqazzaz M, A Samsudin, L Idris, D Ismail, H Akit (2019). Effect of energy to protein ratio using alternative feed ingredients on growth performance and nutrient digestibility in broilers. Ind J Anim Res 53:1069-1073

AOAC (2005). Official Methods of Analysis. AOAC International, Arlington, Virginia, USA

Bartosch S, A Fite, GT Macfarlane, ME McMurdo (2004). Characterization of bacterial communities in feces from healthy elderly volunteers and hospitalized elderly patients by using realtime PCR and effects of antibiotic treatment on the fecal microbiota. Appl Environ Microbiol 70:3575-3581

Borrelli L, L Coretti, L Dipineto, F Bovera, F Menna, L Chiariotti, A Nizza, F Lembo, A Fioretti (2017). Insect-based diet, a promising nutritional source, modulates gut microbiota composition and scfas production in laying hens. Sci Rep 7; Article 16269 
Chen K, H Chang, C Yang, S You, H Jenq, B Yu (2007). Effect of dietary inclusion of dehydrated food waste products on taiwan native chicken (taishi no. 13). Asian-Aust J Anim Sci 20:754-760

Chen T, Y Jin, D Shen (2015). A safety analysis of food waste-derived animal feeds from three typical conversion techniques in China. Waste Manage 45:42-50

Crespo N, E Esteve-Garcia (2001). Dietary fatty acid profile modifies abdominal fat deposition in broiler chickens. Poult Sci 80:71-78

Cutrignelli MI, M Messina, F Tulli, B Randazzo, I Olivotto, L Gasco, R Loponte, F Bovera (2018). Evaluation of an insect meal of the black soldier fly (Hermetia illucens) as soybean substitute: Intestinal morphometry, enzymatic and microbial activity in laying hens. Res Vet Sci 117:209-215

Dierick N, J Decuypere, K Molly, E Van Beek, E Vanderbeke (2002). The combined use of triacylglycerols containing medium-chain fatty acids (mcfas) and exogenous lipolytic enzymes as an alternative for nutritional antibiotics in piglet nutrition: I. In vitro screening of the release of mcfas from selected fat sources by selected exogenous lipolytic enzymes under simulated pig gastric conditions and their effects on the gut flora of piglets. Livest Prod Sci 75:129-142

DiGiacomo K, H Akit, B Leury (2019). Insects: A novel animal-feed protein source for the australian market. Anim Prod Sci 59:2037-2045

Dunkley K, C Dunkley, N Njongmeta, T Callaway, M Hume, L Kubena, D Nisbet, S Ricke (2007). Comparison of in vitro fermentation and molecular microbial profiles of high-fiber feed substrates incubated with chicken cecal inocula. Poult Sci 86:801-810

Frahm E, U Obst (2003). Application of the fluorogenic probe technique (TaqMan PCR) to the detection of Enterococcus spp. and Escherichia coli in water samples. J Microbiol Meth 52:123-131

Hossein S (2015). Growth performance, carcass yield and meat quality of free range chickens fed on diet contained dehydrated processed food waste. Master's thesis. Universiti Putra Malaysia, Selangr, Malaysia

Hossein S, I Dahlan (2015). Growth performance of free-range village chickens fed dehydrated processed food waste. Malays J Anim Sci 18:77-86

Jiménez-Moreno E, M Frikha, AD Coca-Sinova, J García, G Mateos (2013). Oat hulls and sugar beet pulp in diets for broilers 1. Effects on growth performance and nutrient digestibility. Anim Feed Sci Technol 182:33-43

Jiménez-Moreno E, J González-Alvarado, R Lázaro, G Mateos (2009). Effects of type of cereal, heat processing of the cereal, and fiber inclusion in the diet on gizzard ph and nutrient utilization in broilers at different ages. Poult Sci 88:1925-1933

Khatun J, TC Loh, H Akit, HL Foo, R Mohamad (2017). Fatty acid composition, fat deposition, lipogenic gene expression and performance of broiler fed diet supplemented with different sources of oil. Anim Sci J 88:1406-1413

Kroeckel S, A-G Harjes, I Roth, H Katz, S Wuertz, A Susenbeth, C Schulz (2012). When a turbot catches a fly: Evaluation of a pre-pupae meal of the black soldier fly (Hermetia illucens) as fish meal substitutegrowth performance and chitin degradation in juvenile turbot (Psetta maxima). Aquaculture 364:345-352
Marono S, R Loponte, P Lombardi, G Vassalotti, M Pero, F Russo, L Gasco, G Parisi, G Piccolo, S Nizza (2017). Productive performance and blood profiles of laying hens fed hermetia illucens larvae meal as total replacement of soybean meal from 24 to 45 weeks of age. Poult Sci 96:1783-1790

Mateos G, E Jiménez-Moreno, M Serrano, R Lázaro (2012). Poultry response to high levels of dietary fiber sources varying in physical and chemical characteristics. J Appl Poult Res 21:156-174

Nadia N, I Dahlan, H Lokman, T Tee (2016). Effect of different energy to protein ratios in starter diet with dehydrated food waste, superworms and unfertilized eggs on growth performance of village chickens. Malays J Anim Sci 19:15-22

Oluokun J (2000). Upgrading the nutritive value of full-fat soyabeans meal for broiler production with either fishmeal or black soldier fly larvae meal (Hermetia illucens). Nig J Anim Sci 3:51-61

Parfitt J, M Barthel, S Macnaughton (2010). Food waste within food supply chains: Quantification and potential for change to 2050. Phil Trans Roy Soc Lond B Biol Sci 365:3065-3081

Rinttilä T, A Kassinen, E Malinen, L Krogius, A Palva (2004). Development of an extensive set of 16S rDNA-targeted primers for quantification of pathogenic and indigenous bacteria in faecal samples by real-time PCR. J Appl Microbiol 97:1166-1177

Sadeghi A, M Toghyani, A Gheisari (2015). Effect of various fiber types and choice feeding of fiber on performance, gut development, humoral immunity, and fiber preference in broiler chicks. Poult Sci 94:2734-2743

Saki A, M Tabatabie, A Ahamadi, SH Sayer, S Mirzayi, N Kiani (2006). Nutritive value, metabolizable energy and viscosity of kitchenwaste on broiler chicken performance. Pak $J$ Biol Sci 9:1970-1974

Schiavone A, MD Marco, S Martínez, S Dabbou, M Renna, J Madrid, F Hernandez, L Rotolo, P Costa, F Gai (2017). Nutritional value of a partially defatted and a highly defatted black soldier fly larvae (Hermetia illucens L.) meal for broiler chickens: Apparent nutrient digestibility, apparent metabolizable energy and apparent ileal amino acid digestibility. J Anim Sci Biotechnol 8; Article 51

Spranghers T, M Ottoboni, C Klootwijk, A Ovyn, S Deboosere, BD Meulenaer, J Michiels, M Eeckhout, PD Clercq, SD Smet (2017). Nutritional composition of black soldier fly (Hermetia illucens) prepupae reared on different organic waste substrates. J Sci Food Agric 97:2594-2600

Velasco S, L Ortiz, C Alzueta, A Rebole, J Trevino, M Rodriguez (2010). Effect of inulin supplementation and dietary fat source on performance, blood serum metabolites, liver lipids, abdominal fat deposition, and tissue fatty acid composition in broiler chickens. Poult Sci 89:1651-1662

Viana E, HE Schulz, R Albuquerque, AB Noronha (2006). Food residues of domestic waste: Case study of use in broiler chickens feeding. Rev Bras Eng Agríc Amb 10:203-211

Wang RF, WW Cao, CE Cerniglia (1996). PCR detection and quantitation of predominant anaerobic bacteria in human and animal fecal samples. Appl Environ Microbiol 62:1242-1247 